\title{
Georgia State University ScholarWorks@ Georgia State University
}

Geosciences Faculty Publications

Department of Geosciences

1993

\section{Natural Hazards in Puerto Rico}

Risa Palm

Georgia State University, risapalm@gsu.edu

Michael E. Hodgson

University of South Carolina, hodgsonm@sc.edu

Follow this and additional works at: http://scholarworks.gsu.edu/geosciences_facpub

Part of the Geography Commons, and the Geology Commons

\section{Recommended Citation}

Palm, Risa, and Michael E. Hodgson. 1993. "Natural Hazards in Puerto Rico". Geographical Review 83 (3): 280-89. doi:10.2307/ 215730 .

This Article is brought to you for free and open access by the Department of Geosciences at ScholarWorks@ Georgia State University. It has been accepted for inclusion in Geosciences Faculty Publications by an authorized administrator of ScholarWorks @ Georgia State University. For more information, please contact scholarworks@gsu.edu. 


\title{
NATURAL HAZARDS IN PUERTO RICO*
}

\author{
RISA PALM and MICHAEL E. HODGSON
}

ABSTRACT. Puerto Rico faces natural hazards including hurricanes, earthquakes, tsunamis, landslides, subsidence, and flooding. Although Puerto Ricans perceive themselves as highly vulnerable to these hazards, few have adopted mitigation measures except for mandatory insurance.

$\mathrm{T}^{\mathrm{O}}$

OURISM literature portrays Puerto Rico as an American paradise, a destination for tourists interested in the casinos and nightlife of San Juan or the natural beauty of the Caribbean beaches and El Junque National Forest. Yet Puerto Rico also has a sizable potential for natural disasters. Each year, from July to November, a series of hurricanes passes through the Caribbean region. One such storm, Hurricane Hugo, struck Puerto Rico and the Virgin Islands on 18 September 1989 (Fig. 1). Hugo caused an estimated $\$ 1$ billion in damage and destroyed some five thousand homes, especially in areas of unregulated development on hillsides, coastal areas, and floodplains (FEMA 1989).

The aftermath of Hurricane Hugo provided an opportunity to assess attitudes toward and responses to natural hazards, including earthquakes, tsunamis, hurricanes, coastal floods, riverine flooding, and landslides. This article presents an overview of the types of natural hazards that beset Puerto Rico and summarizes the results of a sample survey that measured both the perceived vulnerability to these hazards and the factors that affect the adoption of mitigation measures.

\section{Geophysical SetTing and Hazard Vulnerability}

The interaction of geophysical risk and human settlement makes the Caribbean region especially vulnerable to natural hazards (Cross 1992). Puerto Rico shares in that risk. Situated near the subduction zone between the North American and Caribbean tectonic plates (Fig. 2), Puerto Rico lies in what has been called one of the most earthquake-prone regions of the world (Hays and Gori 1984, 13). The first recorded damaging earthquake, which occurred in the 1520s, destroyed the home of Ponce de León (McCann 1984, 41). Other major earthquakes occurred in 1717, when the San Felipe Church in Arecibo was completely ruined; in 1787, when great damage was done to the El Morro and San Cristóbal forts in San Juan and many churches and large buildings

\footnotetext{
* Research reported here was supported by grant BCS-9017369 from the National Science Foundation. NSF program officer was William Anderson. Faculty collaborators were José Molinelli and Nancy Villanueva; assistants were Denise Blanchard, James Zack, John Carroll, and Augusto F. Gandia-Ojeda.
}

DR. PALM is a professor of geography at the University of Oregon, Eugene, Oregon 97403. DR. HODGSON is an assistant professor of geography at the University of Colorado, Boulder, Colorado 80309.

Copyright (C) 1993 by the American Geographical Society of New York 


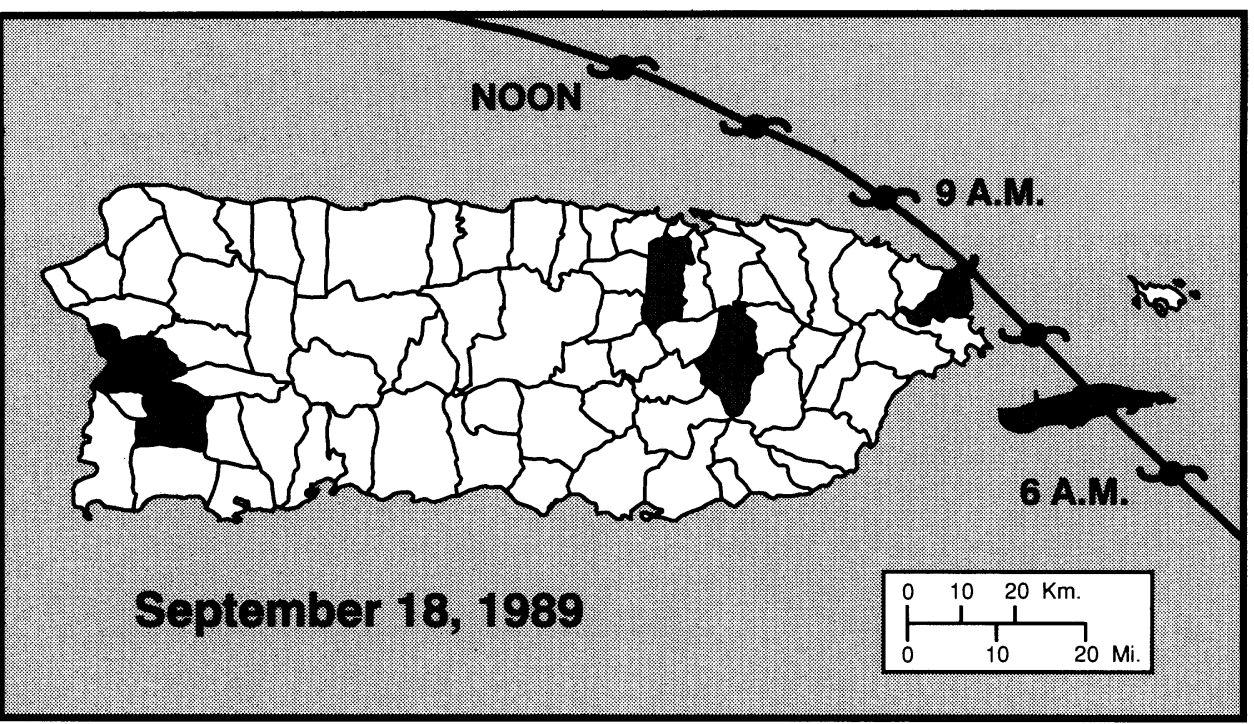

FIG. 1-Track of Hurricane Hugo as it passed Puerto Rico, 18 September 1989. The six municipios surveyed are shown in gray.

were destroyed; and in 1867, when a quake centered in the Virgin Islands caused damage in eastern Puerto Rico. Although the island population has experienced frequent smaller shocks, the last disastrous earthquake occurred in October 1918. This 7.5-magnitude quake, which had its epicenter in the Mona Passage, spurred a tsunami that drowned many residents and destroyed many dwellings on the west coast of Puerto Rico. Overall, the disaster claimed 116 lives and $\$ 4$ million in property damage. Most damage to buildings occurred in areas where the structures had been erected on alluvium.

Areas in the San Juan region are at risk of intense ground shaking, especially along the floodplains of the Río Bayamón, Río Piedras, and Río Grande de Loíza (Molinelli 1987). These floodplains contain large numbers of high-rise buildings and housing units as well as airport facilities, roads, and water mains. In addition, about 17 percent of the region is susceptible to liquefaction, and other areas, especially the southern part of the metropolitan region, face risks of earthquake-induced landslides. The high earthquake vulnerability of Puerto Rico relates to the location of large numbers of buildings and infrastructure in especially hazardous zones. Although earthquakes occur infrequently, a single event can cause catastrophic damage and numerous casualties.

Connected with the earthquake hazard is the risk of seismically induced tsunamis. These cataclysmic waves form when large masses of displaced earth in ocean basins disturb the overlying water column. Generally, tsunamis occur at large subduction zones, as in the Caribbean region. One of the more dramatic tsunamis there occurred on 18 November 1857, triggered by an earthquake in the Anegada trough between St. Croix and St. Thomas. 


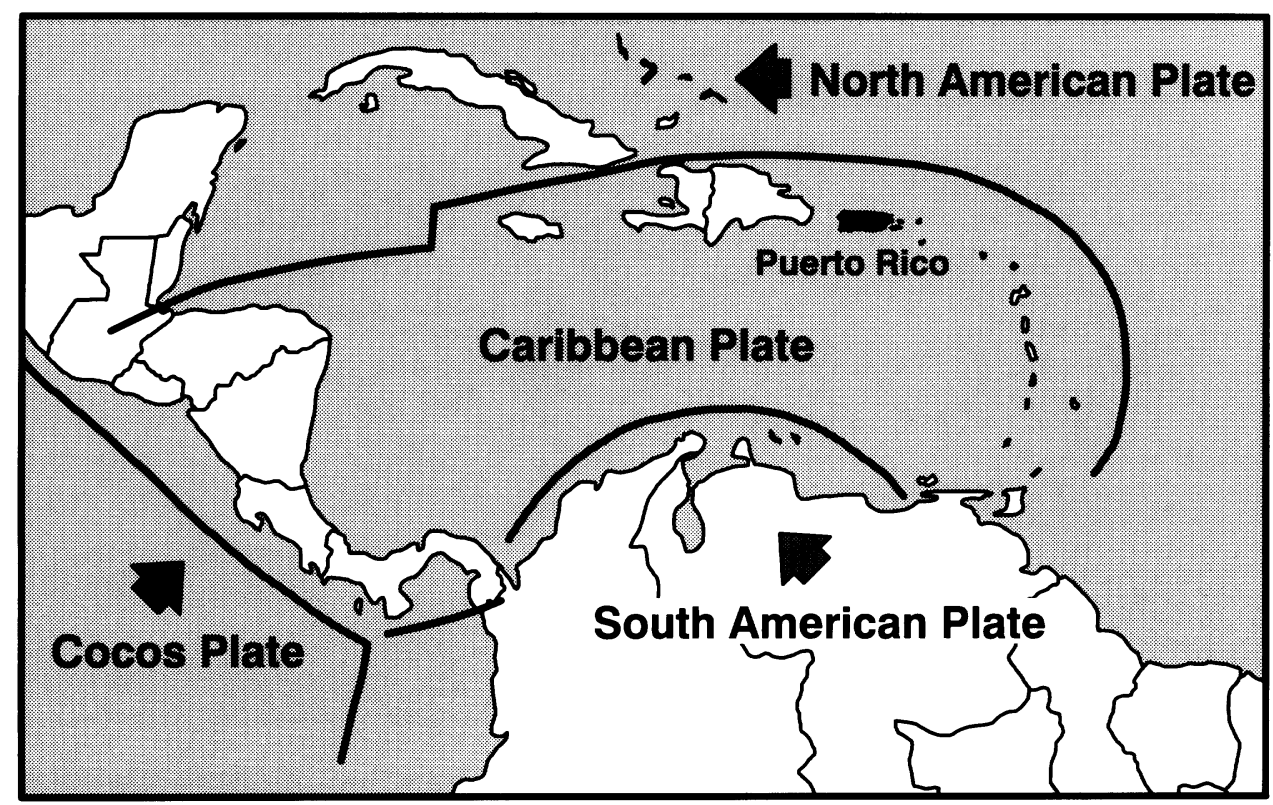

FIG. 2-Plate-tectonic setting.

The event delayed the United States' purchase of the Virgin Islands for fifty years and damaged settlements not only in the Virgin Islands but also in Vieques, Yabucoa, and Fajardo in eastern Puerto Rico (Lander and Lockridge 1989). As noted earlier, another tsunami, which hit the opposite end of the island, was associated with the 1918 earthquake. Some 40 of the 116 fatalities attributable to that quake actually stemmed from the tsunami. Tsunamis in May 1922, associated with an earthquake near Vieques, and in August 1946, tied to an earthquake northeast of the Dominican Republic, also caused damage in Puerto Rico. The large coastal population centers of Mayagüez and San Juan are especially susceptible to this earthquake-related phenomenon.

Hurricanes, among the most devastating of natural hazards, occur frequently in the Caribbean region. A landfalling or coastline-paralleling hurricane brings a storm surge, winds, rainfall, and tornadoes. Of these, storm surge, the rapid rise of sea level, accounts for more than 90 percent of the deaths associated with hurricanes (Pielke 1990, 59).

In the past one hundred years, Puerto Rico has been affected by thirteen landfalling hurricanes and by forty-three additional storms and hurricanes that passed within seventy-five miles of San Juan (Puerto Rico Department of Natural Resources 1980). The August 1899 San Ciriaco hurricane moved from Arroyo to Aguadilla, brought with it twenty-three inches of rain within a twenty-four-hour period, and claimed 2,184 victims and \$35 million in direct damage. The hurricane induced both coastal and riverine flooding; between five hundred and one thousand persons drowned from flooding on 
the Arecibo River. The September 1928 San Felipe II hurricane followed a path similar to that of the San Ciriaco storm, with winds reaching two hundred miles an hour. Around three hundred lives were lost, far fewer than in the 1899 storm, but property damage was enormous: economic losses totaled \$50-\$85 million, and more than 83,000 families were left homeless. The September 1932 San Ciprian hurricane struck the northeastern part of Puerto Rico, killing three hundred persons and causing another $\$ 30-\$ 50$ million in property losses. Tropical Storm Eloise, which passed north of Puerto Rico in September 1975, claimed thirty-four lives, left 120,000 homeless, and caused property damage in excess of \$125 million.

Landfalling hurricanes are capable of horrendous devastation and account for most flood-related damage in Puerto Rico. Because hurricanes cause more property losses annually and occur with greater frequency than do earthquakes, hurricanes are perceived as a familiar annoyance, a part of the environment that island residents must cope with regularly.

Although hurricanes constitute the primary cause of flood damage in Puerto Rico, the island also experiences riverine floods induced by heavy rains not associated with hurricanes. For example, floods in October 1970 in the eastern two-thirds of Puerto Rico caused $\$ 68$ million in damage and eighteen deaths. Total rainfall at some stations for the six-day storm period exceeded thirty-eight inches. Smaller-scale flooding also occurs frequently in Puerto Rico, owing to a combination of moderately heavy rainfall and insufficient or clogged drainage. Like hurricanes, flooding recurs regularly, usually in late summer through early winter, the same time that tropical storms threaten.

Puerto Rico is among the more landslide-prone areas in the United States (Jibson 1987, 183), because of a combination of mountainous terrain and tropical climate. Most common landslides are debris flows and slides, which are especially hazardous because they occur with little advance warning and move very rapidly. In Puerto Rico, as elsewhere, poor landuse and construction practices accentuate vulnerability. Construction of roads and houses contributes to the hazardousness of slides, as along the roadcut and fill slopes in the Caguas-Cayey region (Molinelli 1984). In Mameyes, in the municipio of Ponce, 129 persons died in a landslide associated with an October 1985 storm.

Subsidence and surface collapse likewise result from a combination of natural factors and human activity. Principal causes include withdrawal of large volumes of fluids, such as petroleum or water; drainage of wetland areas, often done to convert them into agricultural land or residential uses; removal of subsurface materials, as with underground mining; application of heavy loads on a subsurface that cannot bear them, as with dense construction; or settling of new land created by artificial fill (Griggs and Gilchrist 1983). Natural factors such as tectonic activity or the formation of sinkholes can also prompt subsidence. In Puerto Rico, rainfall filters through subsurface 
limestone formations to create cavities that eventually become underground rivers and caverns. When the cavern becomes sufficiently large, the roof collapses and a sinkhole is formed. These sinkholes sometimes occur in settled areas, damaging buildings, roads, and other infrastructure.

\section{FACTORS AfFecting HaZARd Response}

Human preparedness and appropriate response to natural hazards can minimize losses of life and property; ignorance and improper responses can multiply those losses. It is therefore as important to understand the perceived vulnerability and associated hazard response as it is to grasp the objective geophysical risks.

Why do individuals adopt or resist hazard-mitigation measures? It has been argued that individual behavior is best understood in the context of the constraints and enablements set by household, community, and society (Palm 1990). An individual may be well aware of a hazard and of the best mitigation measures, but still be constrained from action by powerlessness within the household, by lack of money to adopt the measures, by community or society values, by legal or bureaucratic impediments, or by a host of other factors. Thus no direct, perfect relationship between attitude and behavior exists in the empirical world. Given these constraints, two broad conditions may be identified for appropriate individual or household responses to natural hazards: awareness of the hazard, and translation of that awareness into action.

Awareness of hazards may depend in part on how long an individual has lived in an area and on personal experience with the local hazard conditions. The severity and recency of previous hazard events and the extent of the individual's personal loss in them likewise affect awareness of the hazard.

A large amount of public information, both from governmental sources and from the general knowledge pool, can enhance individual awareness. Governmental agencies have attempted to increase the level of hazard awareness through public-information campaigns, using diverse strategies such as community meetings, brochures, and warnings on inside covers of telephone books; through legislation requiring disclosure of insurance purchase; and through dissemination of materials in public schools. Not all information from such external sources is accepted and believed, however. Risk communication is much more likely to be persuasive if the information source is attractive, if the receiver empathizes with the source, and if the source is credible, trusted, and perceived as having expertise. Additionally, the receiver must be attentive to the message: the issue must be of central interest, and the receiver must accept the credibility of the argument with reference to personal experience, plausibility, and congruence with the value system (Lee 1986; Renn and Levine 1991). 
Has there been a consistent attempt to convey the risks of earthquakes, flooding, and hurricane damage in Puerto Rico, and has the risk communication followed the principles outlined above? Probably not. Furthermore, without a recent history of such a communication effort in Puerto Rico, people there might be expected to harbor relatively inaccurate assessments of personal risk and to have done little to translate perceived vulnerability into mitigation efforts.

Before individuals take action to mitigate risk, they must translate knowledge about that risk into a belief that their own lives and property are vulnerable and into a strategy to reduce that vulnerability. Five factors affect this translation. First, people deal with the hazards that seem more important than other problems of daily life. Although this factor has not been examined in Puerto Rico, one might expect that environmental hazards would have only transient salience there, rising in significance during and immediately after a disaster and then falling to a low level of salience compared with daily concerns such as employment, health care, and crime.

A second factor is the degree to which individuals believe that they control their own destiny. Persons who believe that they can affect their future are more likely to act than those who view themselves as passive victims. Third, the likelihood of taking action is affected by the extent to which individuals have pursued information about the risk (Mileti, Farhar, and Fitzpatrick 1990; Sorensen and Mileti 1991). Fourth, individual calculations of the probability of a hazardous event affects behavior, although these calculations may result in a very different perception of the likelihood of occurrence than would scientific modeling. Fifth, the time frame used in decision making affects individual response (Svenson 1991). An individual who feels committed to an area for a long period may be more likely to respond to hazards with low immediate probabilities but with fairly high cumulative probabilities over time. An individual who expects to live in the area for three years or less is very likely to ignore a low-probability, high-potential-damage risk.

\section{RESEARCH HyPOTHESES AND DESIGN}

These considerations suggested three hypotheses to be investigated in Puerto Rico. First, in view of a relatively low level of risk communication, a consequent lack of awareness of hazards and potential responses, and resource constraints on households, we expected a low rate of adoption of voluntary mitigation measures other than insurance. Second, based on previous empirical research in California (Palm and Hodgson 1992), we expected a relatively low rate of adoption of earthquake insurance, and that the rate would not be affected by the mortgage status of the homeowner. Third, because hurricanes occur in Puerto Rico more frequently than do earthquakes, we expected to find relatively higher levels of concern among residents regarding hurricane hazards. 
To test these hypotheses in the context of the aftermath of Hurricane Hugo, we selected six municipios from three types of damage regions (Fig. 1). The municipios are Vieques and Fajardo, in the area of greatest damage; Bayamón and Caguas, in the area of moderate damage; and San Germán and Mayagüez, in the area only indirectly affected by the hurricane. A fourteenpage questionnaire was developed in English, translated into Spanish by project collaborators at the University of Puerto Rico, and reviewed both by an advisory committee of insurance and banking executives and by governmental officials. The survey asked questions about experience with Hurricane Hugo, perceived hurricane, earthquake, and flood hazards, adoption of mitigation measures for all three hazards, perceived vulnerability of the home community to various hazards, and demographic variables such as age, income, and educational level. A statistically random sample was drawn from a complete tax-assessment list of single-family, detached, owner-occupied houses in each of the six municipios. The mail survey of approximately thirteen hundred households was conducted between June and August 1991. Response rates varied from 80.7 percent in Mayagüez to 70.0 percent in Vieques.

\section{EMPIRICAL RESULTS}

As expected, low rates of voluntary mitigation of hurricane risks were found in Puerto Rico. Overall, 27 percent of the survey respondents claimed to have acted to mitigate future damage from hurricanes. Such activities included reinforcement of windows, doors, and roofs, purchase of emergency supplies, and clearing of trees. Most of these activities were cost-free or very inexpensive; only 2 percent of the respondents claimed to have spent more than one hundred dollars on mitigation measures. The percentage of homeowners in each municipio who undertook mitigation measures varied directly with either the experience with Hurricane Hugo or knowledge about the risk from hurricanes. For instance, 44 percent of homeowners in hardhit Vieques took some measures, but only 12 percent in indirectly affected Mayagüez did so.

Only 2 percent of the survey respondents indicated that they took measures to protect their homes against future earthquake hazards. This proportion is smaller than that in California, where approximately 10 percent of homeowners had taken earthquake-mitigation measures other than insurance purchase (Palm and others 1990). Two factors may account for the lower rate of earthquake mitigation in Puerto Rico: experience with earthquakes and house construction. Puerto Rico has not had a major earthquake since 1918, whereas California has damaging earthquakes every few years. Thus few Puerto Ricans and relatively many Californians have direct experience with damaging earthquakes. Also, structural modifications in Puerto Rico, where most housing is of concrete or block construction, are considerably more expensive than structural modifications in California, where 
wood-frame construction predominates. Wood-frame construction is considerably more resistant to earthquake shaking than is concrete or block construction.

Few homeowners in Puerto Rico have undertaken floodproofing activities, but those who did were clustered geographically. Only 5 percent of the survey respondents reported mitigating future flood hazards; of this small proportion, 42 percent resided in Fajardo.

Most damage from natural hazards is included in general homeowner insurance policies covering fire and wind damage. This type of policy is required by lenders throughout the United States and in Puerto Rico as a condition for a mortgage loan. Additionally, federally subsidized flood insurance from the Flood Insurance Administration is required by lenders in communities that participate in the federal flood-insurance program. All of Puerto Rico is included in this program, and it is therefore assumed that lenders are requiring flood insurance for all houses located in a FEMAdesignated one-hundred-year floodplain.

Earthquake insurance usually is not required as a condition for a mortgage loan in the United States. However, in Puerto Rico, virtually all homeowners with a mortgage are required to carry earthquake insurance. The reason is that the largest of the secondary mortgage-market participants-the Federal National Mortgage Association (FNMA)-requires earthquake insurance on packages of mortgages originating in Puerto Rico. Interestingly, it has no such requirement elsewhere, California included. Thus virtually all homeowners in Puerto Rico with a mortgage have earthquake insurance. Those without a mortgage have a choice and tend not to carry such insurance. Of the 194 such respondents to the survey, only thirteen had voluntarily purchased earthquake insurance.

This finding differs sharply with the situation in California, where the decision to purchase catastrophic earthquake insurance is almost always made solely by the individual rather than the lender. Thus, in California, 33 percent of the people with a mortgage and 34.2 percent of those without one purchased earthquake insurance. The difference in the likelihood of insurance purchase did not vary significantly according to mortgage status, and the rate of voluntary purchase was far higher than in Puerto Rico.

Our final set of hypotheses focuses on the idea that because hurricanes have greater frequency and, presumably, greater salience in Puerto Rico than do earthquakes, residents would be more concerned with the former than with the latter. Instead, the survey results suggest that earthquakes are far more frightening than are hurricanes to Puerto Ricans. Only 37 percent of the respondents noted that they were highly or very highly concerned about hurricanes, but 58 percent expressed this level of concern about earthquakes. This relative level of concern about earthquake damage seems rather curious, as the last major damaging earthquake in Puerto Rico occurred in 1918; however, a great deal of recent publicity about earthquake vulnerability may have affected this perception. 
A comparison of responses on this issue from Puerto Rico with those from California is revealing. Objectively, California respondents have a far greater probability of experiencing earthquake damage to their houses during the next decade. Yet Puerto Rican respondents, whether or not insured, are more likely to believe that a damaging earthquake is very apt to affect their home. Only 17.7 percent of the uninsured in Puerto Rico but 43 percent of the uninsured in California said they thought such an earthquake is not very likely; conversely, 54 percent of the uninsured Puerto Ricans but only 8 percent of the uninsured Californians believed that such an earthquake is very likely. Thus Puerto Ricans appear to perceive themselves at greater personal risk from earthquakes than do California residents.

An explanation of these findings must be speculative. Lack of personal experience with earthquakes may make them seem more terrifying in Puerto Rico (Slovic 1987); cultural differences or differing assumptions about the geological structure of the two areas may induce more fear among Puerto Ricans. Issues of translation may also affect the results. In any event, this unexpected finding clearly merits analysis in the context of the cultural and environmental differences between the two regions.

\section{POLICY IMPLICATIONS}

This study of hazards responses in Puerto Rico has several implications for public policy. First, Puerto Ricans are far more concerned with the earthquake hazard than they are with the more common occurrence of flooding and hurricanes. This concern should be used by the nascent seismic-safety commission in Puerto Rico to bring about landuse controls and to upgrade construction regulations. Public agencies should also attempt to convince Puerto Ricans to invest in some inexpensive, simple measures to increase preparedness and to reduce damage in areas especially susceptible to various geophysical events.

A second finding is the sharp influence of external factors on insurance purchase. In Puerto Rico, but not in California, all homeowners with a mortgage are required to purchase earthquake insurance and to pay for it as part of the mortgage escrow. The lending industry in Puerto Rico might reasonably question the FNMA requirements of earthquake insurance, which increase cost of homeownership there and are not applied in areas of greater seismic risk such as Alaska and California.

Residents of Puerto Rico, local officials and citizens alike, responded in an organized and effective manner to Hurricane Hugo, the most devastating storm to affect the island in more than thirty years. Yet disaster awaits; according to some studies, Puerto Rico remains vulnerable to earthquakes of a magnitude equivalent to the Loma Prieta earthquake in California, and the danger of another major hurricane recurs between June and November of each year. Puerto Rican homeowners have invested little in mitigation measures, and there is a clear economic vulnerability to future disaster im- 
pacts, especially among the uninsured, low-income population now carrying no mortgage debt. This study shows that a high level of concern exists among Puerto Ricans to natural disasters in their local areas. One hopes that this concern can be translated into a heightened degree of preparedness against the next major hurricane or earthquake, which are certainties in the future.

\section{REFERENCES}

Cross, J. A. 1992. Natural hazards within the West Indies. Journal of Geography 91:190-199.

FEMA (Federal Emergency Management Agency). 1989. Hazard mitigation opportunities in Puerto Rico. Interagency Hazard Mitigation team, FEMA-842-DR-Puerto Rico, October.

Griggs, G. B., and J. A. Gilchrist. 1983. Geologic hazards, resources, and environmental planning. 2d ed. Belmont, Cal.: Wadsworth.

Hays, W. W., and P. Gori, eds. 1984. A workshop on geologic hazards in Puerto Rico. Open-file report 84-761, U.S. Geological Survey, Reston, Va.

Jibson, R. W. 1987. Landslide hazards in Puerto Rico. A workshop on "assessment of geologic hazards and risk in Puerto Rico," eds. W. Hays and P. Gori, 183-188. Open-file report 87-008, U.S. Geological Survey, Reston, Va.

Lander, J. F., and P. A. Lockridge. 1989. United States tsunamis: 1690-1988. Publication 41-2, National Geophysical Data Center, Boulder, Colo.

Lee, T. R. 1986. Effective communication of information about chemical hazards. Science of the Total Environment 51:149-183.

McCann, W. 1984. The earthquakes hazards of Puerto Rico and the Virgin Islands. A workshop on "geologic hazards in Puerto Rico," eds. W. Hays and P. Gori, 53-72. Open-file report 85731, U.S. Geological Survey, Reston, Va.

Mileti, D. S., B. C. Farhar, and C. Fitzpatrick. 1990. How to issue and manage public earthquake risk information: lessons from the Parkfield earthquake prediction experiment. Colorado State University, Hazards Assessment Laboratory and Department of Sociology, Fort Collins.

Molinelli, J. 1984. Rapid mass movement as a geologic hazard in Puerto Rico. A workshop on "geologic hazards in Puerto Rico," eds. W. Hays and P. Gori, 80-85. Open-file report 84-761, U.S. Geological Survey, Reston, Va.

- 1987. Earthquake vulnerability study for the metropolitan area of San Juan, Puerto Rico. Proceedings, Hazard Mapping meeting, Kingston, Jamaica, 71-86.

Palm, R. 1990. An integrative theory of environmental hazards research. Baltimore: Johns Hopkins University Press.

Palm, R., and M. E. Hodgson. 1992. After a California earthquake: attitude and behavior change. University of Chicago geography research paper 233. Chicago: University of Chicago Press.

Palm, R., M. E. Hodgson, D. Blanchard, and D. Lyons. 1990. Earthquake insurance in California: environmental policy and individual decision-making. Boulder, Colo.: Westview Press.

Pielke, R. A. 1990. The hurricane. London: Routledge.

Puerto Rico Department of Natural Resources. 1980. Coastal flood hazards and responses in Puerto Rico: an overview. San Juan.

Renn, O., and D. Levine. 1991. Credibility and trust in risk communication. Communicating risks to the public, eds. R. E. Kasperson and P. J. M. Stallen, 175-218. Dordrecht: Kluwer.

Slovic, P. 1987. Perception of risk. Science 236: 280-285.

Sorenson, J., and D. Mileti. 1991. Risk communication in emergencies. Communicating risks to the public, eds. R. E. Kasperson and P. J. M. Stallen, 367-392. Dordrecht: Kluwer.

Svenson, O. 1991. Time dimension in perception and communication of risk. Communicating risks to the public, eds. R. E. Kasperson and P. J. M. Stallen, 263-285. Dordrecht: Kluwer. 